舌癌の実験的形成に関する研究

第12編 舌背部における発癌剤の単純塗布による舌癌形成過程の組織学的研究

賀来 亨一藤田浄 秀* - 小田島哲世・早津良和**

玄番涼一**.今井頼子**・鈴木明人**

\title{
Studies on experimental production of carcinoma of the tongue
}

\section{Histological changes in the carcinogenesis of the midportion of the dorsum of the tongue by DMBA painting alone.}

\author{
Tohru KakU - Kiyohide Fujita*. Tetsuyo Odajima - Yoshikazu Hayatsu** \\ Ryo-ichi Genba** . Yoriko Imai** . Akito SuzuKI**
}

\section{は じめに}

われわれは，八ムスターの舌側縁中 $1 / 3$ 部に機械的損 傷を加えると同時に 0.5\% 9,10-dimethyl-1,2-benzanthracene（以下 DMBA と略）アセトン溶液を反復叙布 する方法によって，従来困難と考えられていた舌癌を短 期間に，しかも高率に形成しらることを見い出すととも に，歯科用クレンザーで擦過することによって粘膜に機 械的損傷を与去ながら発癌剤を塗布すると，単に発癌剂 の塗布のみを行う（単純叙布）上りも有意の差をもって 早期に舌癌が形成されることを認めた1,2). その後われわ れは，この早期に舌癌が形成されるといら理由から，

“歯科用クレンザーで擦過すると同時に発癌剤を塗布す る方法”によって舌癌を形成し，舌癌の形成に影響を及 ぼす諸因子の検討，あるいは舌の種々の部位に打ける舌 癌形成過程の組織学的観察などの一連の研究を行ってき $た^{3 \sim 14)}$.

札沅医科大学病理学教室（主任：小野江為則教 授）

* 横浜市立大学口腔外科学教室（主任：大谷隆俊 教授）

** 札幌医科大学口腔外科学教室（主任：小浜源郁 教授)

Department of Pathology, Sapporo Medical College (Chief: Prof. Tamenori Onoé)

* Department of Oral Surgery, School of Medicine, Yokohama City University (Chief: Prof. Takatoshi Ohtani)

** Department of Oral Surgery, Sapporo Medical College (Chief: Prof. Gen-iku Kohama) 受付日：昭和 52 年 10 月 28 日
しかし, 口腔粘膜癌の実験的形成において, この機械 的損傷が，尰瘍の形成に要する期間を短縮するほかに， 形成される腫瘍の肉眼的形態や組織像にいかなる影響を 及注するのなのかを検討する必要がある。このため前回 は, 舌側縁中 $1 / 3$ 部において発癌剤の塗布のみを行った 場合の舌癌形成過程を観察し，これを同じく舌 侧縁 中 $1 / 3$ 部において機械的損傷を与えながら発癌剤を塗布し た場合の舌癌形成過程と比較検討することにより，いわ ゆる “機械的刺激”の意義について考察した ${ }^{14)}$.

今回は, 舌背中央部において発癌剤の塗布のみを行っ た場合の舌癌形成過程を組織学的に觀察し，その観察結 果を同じく舌背中央部において機械的損傷を与えながら 発癌剤の塗布を行った場合の舌癌形成過程9)と比較して みた。

\section{実験材料ならびに方法}

実験動物は, 生後約 2 か月の雄ハムスタ一（Mesocricetus auratus) で, 固型飼料之水を常時与えた. 発癌 剂は $0.5 \%$ DMBA アセトン溶液とし, 毎週 3 回, エー テル麻酔下に, 舌背中央部に発癌剤の塗布のみを行っ た。

使用したのべ動物数は約60匹であった。

得られた舌は矢状断で組織学的観察を行った。

\section{実 験 成 績}

\section{肉眼所見}

ハムスターの正常な舌背面は, 舌乳頭を有する厚い粘 膜でお括われている. 舌乳頭は舌背中央部では最も著明 に認められるが，舌尖部付近や舌根部では，あまり藷明 でない. 実験部位として選んだ舌背中央部は, 肉眼的に 
最も舌乳頭の発達している部分である.

実験開始後第 9 週目までは, 塗布部位の粘膜にはほと んど変化が認められない（写真 1).

第10週目ごろから，塗布部位の個々の舌乳頭が増大し てめだってくる、第17週目ごろから，塗布部位に一致し て個々の舌乳頭が肥大したような小腫瘤が認められるよ らになり，しか子小腫瘤は通常多発性に形成される（写 真 2). さらに発癌剤の塗布を反復するに従って，これ らの小腫瘤は徐々に大きさを增していき，互いに癒合す るようになる（写真 3).

反復塗布を続けるらちに, 粘膜は白色調と粗粘性を增 し（写真 4，5，9），実験開始後第43週目ごろより，小 腫瘤は大きさを增して明らかな外向性の腫瘤を形成して くる（写真 $6,7,10,11$ ). しかし, 舌側縁中 $1 / 3$ 部に 認められたような大きな外向性腫瘤 ${ }^{11)}$ は形成されること はなく, 実験開始後第54週目ごろより腫瘤表面がびらん を呈するようになり, 癌を思わせるにいたる(写真 12). 腫瘤が外向性にあまり大きく形成されないので，時期が すすんで上皮性成分が豊富になってくると，腫瘍組織は 舌筋内に下向性内向性に增殖していくようにみえてく る. 外向性腫瘤が全く形成されずに, 癌性変化がはじめ から澬瘍として始まったと思われる例は認められなかっ た.

\section{組織学的所見}

八ムスターの正常な舌背面は, 手状乳頭を有する厚い 粘膜でおおわれている.この系状乳頭は舌背中央部で最 もよく発澾している. 系状乳頭の尖端は舌根部の方向に 傾き, 凸面は舌尖部の方向に, 四面は舌根部の方向に面 している，角化層は厚く，基底層は乳頭に一致して凹凸 が著明である. 舌粘膜と舌筋との間に少量の結合織が認 められる。

単純淕布による舌癌の形成過程は, 塗布部位に一致し て筋層内に脂肪浸潤が認められ，次第に粘膜下組織が厚 さを增し, その後, 多数例においては系状乳頭が不規則 となり，互いに癒合して乳頭腫様の外向性腫瘤を形成す る過程で癌性変化が明らかとなり, 少数例においては上 皮が下向性に増殖する過程で, 癌性変化にいたると思わ れる所見を得た。そこで，舌背中央部における舌癌の形 成過程を，1）初期，2）系状乳頭肥大期，3）乳頭腫 形成期または下向性增殖期，4）癌形成期の 4 期に分 け，以下に記載することとする。

1）初期：実験開始から塗布部位に一致して粘膜下結 合組織の幅が増し，肪層には脂肪浸潤が認められるまで の期間で，だいたい実験開始後 3 週問である。この期に は, 粘膜上皮には組織学的に明らかな変化は認められな い.

2) 系状乳頭肥大期: 实駼開始後第 4 週目から第32週 目までであり，染布部位に一致して筋居内に脂肪浸洞が 認められ，系状乳頭は形が不規則になり，基底層は規則
的な凹凸を失い, 乳頭層の結合組織や粘膜下結合組織の 幅が增加するようになる。塗布を続けていくらちに，幅 を增した結合組織の中に 2 次乳頭が形成されたり,さら に基底膜の凹凸が不規則となり，クロマチンの豊富な細 胞が多くなる（写真 13，14）。

3) 乳頭腫形成期または下向性增殖期 : 染布部位に小 腫瘤が形成されてから癌性変化が認められるまでの期間 で，だいたい実験開始後第33週目から第53週目までであ る.

この期に認められる小腫瘤は, 乳頭の結合組織の中に 上皮が深く侵入し, 明らかに乳頭腫の組織像を呈するも のである（写真 15，16）. 肉眼的に小腫瘤が認められて も, 組織学的には乳頭の結合組織の幅が増しているたけ で、まだ上皮の侵入の認められないものは系状乳頭肥大 期に含まれる。

乳頭腫の上皮の層構造は次第に乱れを示し, 細胞の大 小不同や細胞の異型性が顕著となり, 乳頭状突起より第 2 次の突起が周辺に管出する像が認められるようになる (写真 17, 18).

少数例においては, 肉眼的には粘膜面は粗 粆である が，乳頭腫の形成は認められず，上皮は笳層を圧排する 上らに内向性下向性に增殖し, 上皮の細胞密度は高くな り, 細胞巽型性が影著となる（写真 19〜22）。しかし， この下向性内向性增殖はむしろ軽度で, 機械的損傷を与 えながら発癌沜を塗布した場合9)のよらに，筋層内に非 常に深くまで侵入しないよらである。

4) 癌形成期 : 癌は実験開始後第 54 迵目以後に認めら れる。

基本的には, 乳頭腫の組織像の一部に上皮性細胞が結 合組織中に浸潤性に增殖している部分, あるいは細胞密 度の高い部分が認められ, 層構造の乱れと細胞異型性が 明らかとなり，さらに䇨層内に腫愓細胞が浸潤している 組織像などが認められるようになる（写真 25〜30).

形成された舌癌の分化度は種々であるが, 分化度の高 いものが多く、極端に低いものは認められなかった。

腫拱組織が舌の後方部や口底部にまで広沉に浸潤した 例は, 認められなかった。

\section{考按}

以上の肉腿的ならびに組織学的観察から明らかなよ5 に，八ムスターの舌背中央部に $0.5 \%$ DMBA アセトン 溶液の塗布のみ (単純塗布) を行っても舌癌が形成され る.この舌癌の形成過程は, 組 織学的に，1）初期, 2) 系状乳頭肥大期，3) 乳頭腫形成期または下向性增 殖期，4）癌形成期の 4 期に大別される。

まず, 単純濯们を行った本吥究の舌癌形成過程を, 同 しく舌背中央部に拈いて機械的損伤を与えながら，発癌 剂の塗布を行った場合の舌癌形成過程と此洨してみる。 
表 1 舌侧緑中 $1 / 3$ 部と舌背中央部における実験方法の遱いと舌癌形成過程との関係

\begin{tabular}{|c|c|c|c|c|c|c|}
\hline \multirow{2}{*}{ 実匬方法 } & \multirow{2}{*}{ 実 験 部 位 } & \multicolumn{4}{|c|}{ 舌 癌 形 成 過 程 } & \multirow{2}{*}{ 備 } \\
\hline & & 第 I 期 & 第 II 期 & 第 $\mathbb{I I}$ 期 & 第IV 期 & \\
\hline \multirow{2}{*}{ 単純洤布法 } & 舌側縁中 $1 / 3$ 部 & 初 期 & びまん性增生期 & $\begin{array}{c}\text { 乳頭腫形成期 } \\
\text { または } \\
\text { 表面增殖期 }\end{array}$ & 痛形成期 & \multirow[t]{2}{*}{ 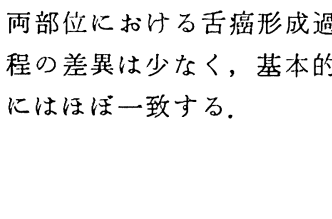 } \\
\hline & 舌 背 中 央 部 & 初 期 & 系状乳頭肥大期 & $\begin{array}{c}\text { 孚頭腫形成期 } \\
\text { または } \\
\text { 下向性增殖期 }\end{array}$ & 癌形成期 & \\
\hline \multirow{2}{*}{ 併用㳂布法 } & 舌側緑中 $1 / 3$ 部 & 初 期 & びまん性增生期 & 乳頭腫形成期 & 癌形成期 & \multirow{2}{*}{$\begin{array}{l}\text { 両部位における舌癌形成過 } \\
\text { 程の差が大きい. }\end{array}$} \\
\hline & 舌背 中央 部 & 初 期 & びまん性增生期 & 下向性增殖期 & 癌形成期 & \\
\hline
\end{tabular}

実験開始から舌癌が認められるまでの期間は，単純塗 布では54週であるが，機械的損傷を与えると同時に発癌 剂を塗布した場合は23週で9)，機械的損傷を与皇た場合 のほうがはるかに短いといえる。

肉眼的形態は, 単純塗布では通常, 多発性に小腫瘤が 形成され，この小腫瘤が瘉合して徐々に大きさを增して いく過程で癌を思わせるようになる。これに対して，機 械的損傷を与えた塗布では，基本的には外向性腫瘤は形 成されず，舌癌は肉眼的には潰瘍として認められた9） 両者は，この点で大きく異なる。

組織像に関しては，単純塗布では多数例において，は じめ糸状乳頭の結合組織の幅が増し，また粘膜下結合組 織の幅が増し，この結合組織中に上皮性成分が侵入する ように增殖して乳頭腫を形成し，これを基盤に悪性変化 が認められ，少数例においては上皮性成分が下向性内向 性に増殖する過程で, 悪性変化が認められる。これに対 して，機械的損傷を与えた塗布では，基本的には上皮性 成分が下向性内向性に増殖する過程, 悪性変化が認めら れた9)。両者は組織像に関しても，その形成過程は大き く異なる。しかし，角化の程度は，両者とも分化度の高 い舌癌がむしろ多く，大きな差異はないようである.

次に，同じく単純塗布によって舌癌を形成した舌側縁 中 $1 / 3$ 部における形成過程と舌背中央部における形成過 程と比較してみると，もちろん両者は種々の点で異なる が，基本的には両者とも多発性に小腫瘤が形成され，そ れらが增大し癒合する過程で乳頭腫を形成し，これを基 盤にして舌癌が形成されるとい5点では一致する（表 $1)$.

部位が異なり，いままでの研究結果 ${ }^{14}$ からは全く異 なった形成過程で，舌癌が形成されると考えられた舌側 縁中 $1 / 3$ 部と舌背中央部との両部位が，単純塗布では基 本的に乳頭腫の組織構造を基盤として舌癌が形成される という事实は，まことに注目すべきことである。

はじめに述べたように，われわれは，“歯科用クレン

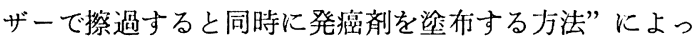
て舌癌を形成して一連の研究 ${ }^{14}$ 14) 行ってきた，その研
究結果から, 舌側縁中 $1 / 3$ 部では全例に乳頭腫様腫瘤が 形成され，これを基盤にして舌癌が形成され 七 $^{3}$ ，舌背中 央部では乳頭腫様腫瘤はほとんど認められず，粘膜上皮 が下向性に增殖する過程で舌癌が認められる9）と考えら れたわけだが，舌側縁中 $1 / 3$ 部と舌背中央部の単純鉒布 による形成過程といままでの研究結果とを総合的に考え てみると，この差異は，機械的損傷を与えながら慗布し たために，発癌剤に対する反応のほかにその機械的損傷 に対する組織反応なども加わって，これらの部位におけ る本来の形成過程が大きく修飾された結果であると思わ れる。

以上から, 舌背中央部における舌癌の形成過程に及ぼ す機械的損傷の意義は，

1) 舌癌の形成に要する期間を短縮する.

2 ）粘膜上皮の増殖に際し，下向性内向性に増殖する 方向に修飾する。

その結果, 舌癌は肉眼的には“潰瘍”として始まり, endophytic の舌癌を多く形成する.

と要約されると思われる。

また，機械的損傷に対する反応は，舌側縁中 $1 / 3$ 部と 舌背中央部とでは大きく異なることが知られた ${ }^{3,9)}$. その 組織構造の類似性から推測して，ヒトの口腔癌にあって も煩粘膜・舌下面のごとき lining mucosa や䨑肉・口蓋 粘膜のごとき masticatory mucosa あるいは specialized mucosa ${ }^{15)}$ など，部位によって，いわゆる“機械的刺激” に対する反応は大きく異なると考えられる。今後，この 点をも解明していきたいと考える。

\section{結語}

八ムスターの舌背中央部において, 発癌凧の単純塗布 による舌癌の形成過程を組織学的に観察し, 以下の結論 を得た。

1) 組織学的に, 舌癌の形成過程は, (1) 初期, 2 系状 乳頭肥大期，(3)乳頭腫形成期または下向性增殖期，(4)癌 形成期の 4 期に分かつことができる. 
2) 早期舌癌は乳頭腫の組織構造を基盤として形成さ れると考えられる。

3）単純塗布による舌癌の形成過程と機械的損傷を与 えると同時に発癌剤を塗布した場合の形成過程の比較か ら，機械的損傷が舌背中央部における舌癌の形成過程に 及ぽす影響は，

(1)舌癌の形成に要する期間を短縮する.

(2)粘膜上皮の増殖に際し，下向性内向性に増殖する 方向に修飾する。

この 2 点に要約される.

擱筆するに際し，御校閲をいただいた札幌医科大学病 理学小野江為則教授に感謝の意を表する.

な扣，本研究は，佐々木元䝨教授が札幌医科大学口院 外科学諈座に在職中に行われたものである。ここに記し て感謝の意を表する。

\section{文献}

1) Fujita, K., Kaku, T., Sasaki, M., and Onoe, T.: Experimental production of lingual carcinomas in hamsters by local application of 9, 10-dimethyl-1, 2-benzanthracene. J Dent Res 52: 3271973.

2）藤田浄秀, 賀来亭, 佐々木元賢, 小野江為 則：舌癌の実験的形成に関する研究第 1 編 9, 10-dimethyl-1, 2-benzanthracene の染布によ る舌癌の実験的形成。口科誌 21：999 1972.

3）藤田浄秀, 賀来亨, 佐々木元留, 小野江為 則：舌癌の実験的形成に関する研究第 2 編 舌瘤形成過程の組織学的研究. 口科誌 $22: 64$ 1973.

4）藤田浄秀, 賀来 亨, 佐々木元䝨, 小野江為 則：舌瘦の实臨的形成に関する研究第 3 編 実験動物の月龄差が舌癌の形成に打よぼす影复. 日口外誌 18：486 1972 .

5）藤田浄秀, 賀来 亨, 佐々木元賢: 舌瘦の実験 的形成に関する研究第 4 編 舌癌形成の部位
的差異に関する研究. 口科誌 22: 3621973.

6) Fujita, K., Kaku, T., Sasaki, M., and Onoé, T.: Experimental production of lingual carcinomas in hamsters: tumor characteristics and site of formation. J Dent Res 52: 1176 1973.

7）賀来 亨, 脉田浄秀, 佐々木元蜸：舌癌の実験 的形成に関する研究第 5 編各種発痹剂によ る舌癌の実験的形成。日口外誌 19：254 1973.

8）藤田浄秀，賀来 亭，佐々木元留：舌瘐の実験 的形成に関する研究 第 6 編 実験動物の性差 ならびに発癌㶡の塗布頻度の差が舌癌の形成に およぼす影稫。日口外誌 19：2591973.

9）藤田浄秀，賀来 亨，佐々木元䝨：舌癌の実臨 的形成に関する研究 第 7 編 舌背部における 舌癌形成過程の組織学的研究。口科誌 $22: 550$ 1973.

10）賀来 亨, 藤田浄秀, 佐々木元賢：舌瘦の実臨 的形成に関する研究 第 8 編 舌下面部におけ る舌癌形成過程の組織学的研究. 口科誌 23 : 471974.

11）賀来 亨, 藤田浄秀, 小田島 哲世, 佐々木元 䝨: 舌癌の実臨的形成に関する研究 第 9 編 舌尖部に扣ける舌癌形成過程の組織学的研究. 口科誌 23: 6441974.

12）藤田浄秀, 賀来烹, 小田島哲世, 佐々木元 䝨: 舌癌の実鍳的形成に関する研究 第10編 舌側縁前 $1 / 3$ 部に打ける舌癌形成過程の組織学 的研究. 日口外誌 21：250 1975 .

13）藤田浄秀, 賀来 亨, 黒木信雄, 早津良和, 陳 元徳, 佐々木元賢 : 舌の早期瘦性変化に関する 実験的研究 (予報)。 日口外誌 20：418 1974 .

14）藤田浄秀, 賀来 亨, 小田島哲世, 早津良和, 鉿木明人，玄番涼一，佐々木元賢 : 舌癌の実䀦 的形成に関する研究第 11 編 舌側縁中 $1 / 3$ 部 に拈ける発癌剤の単純塗布による舌癌形成過程 の組織学的研究. 日口外誌 22: 2591976.

15) Harry Sicher: Orban's histology and embryology. ed 51 C.V. Mosby Co, St Louis, 1966, p 220 . 


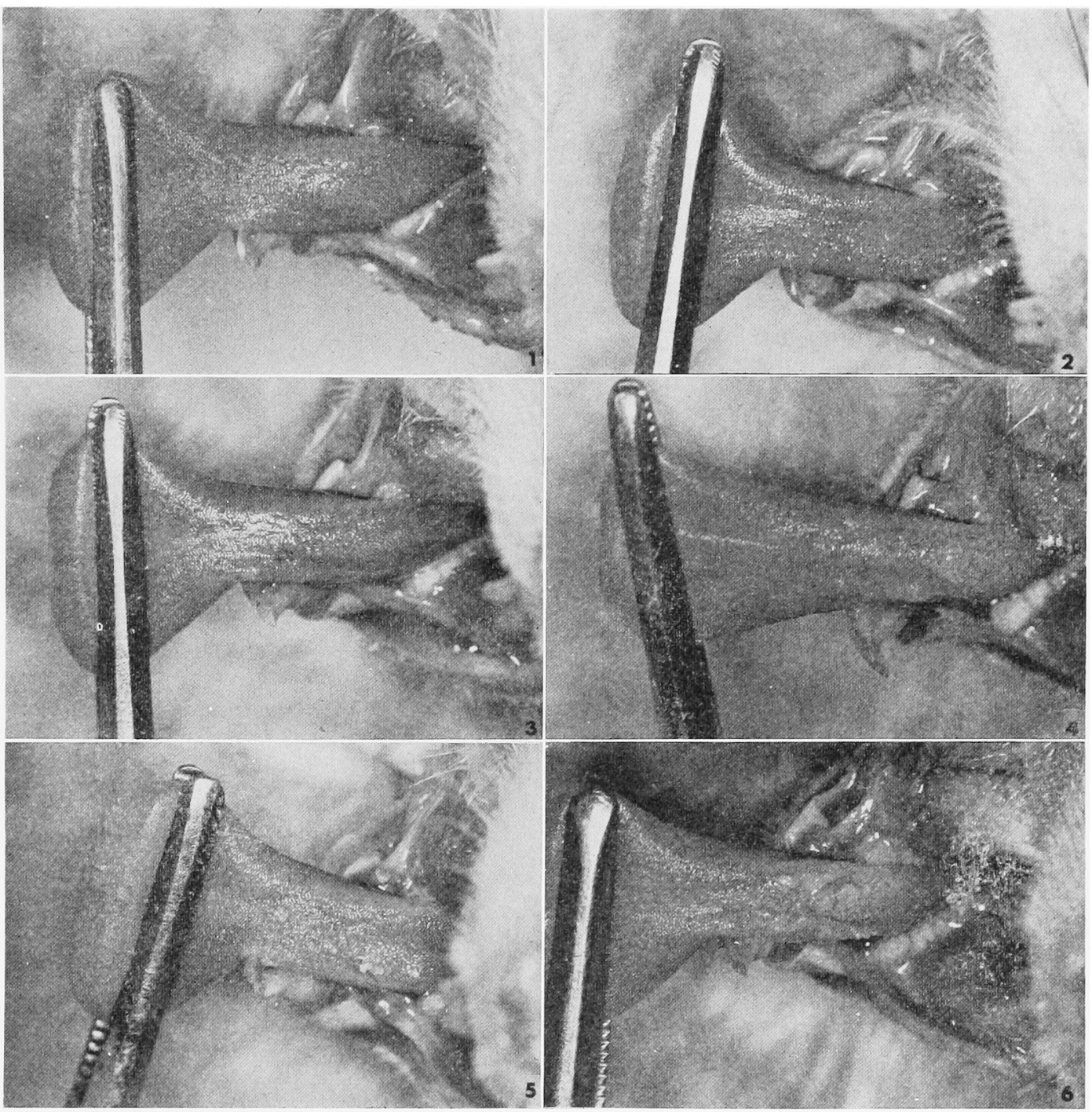

写真 $1:$ 実験開始後 9 週目

肉眼的には，汪とんど変化が認められない。

写真 2: 実鈳開始後 17 週目

塗布部位に一致して，舌乳頭の肥大が認如る。

写真 $3:$ 実験開始後 29 週目

洷布部位に一致して，舌乳頭の肥大がさらに顕著になる。

写真 $4:$ 実験開始後33週目

粘膜は白色調を增し，小尰溜の多発が認められる。

写真 $5:$ 実駼開始後 36 週目

小尰瘤は癌合して，やや大きな連瘤を形成している。

写真 $6:$ 実験開始後 43 週目

不規則な形の腫瘤形成が热められる。 


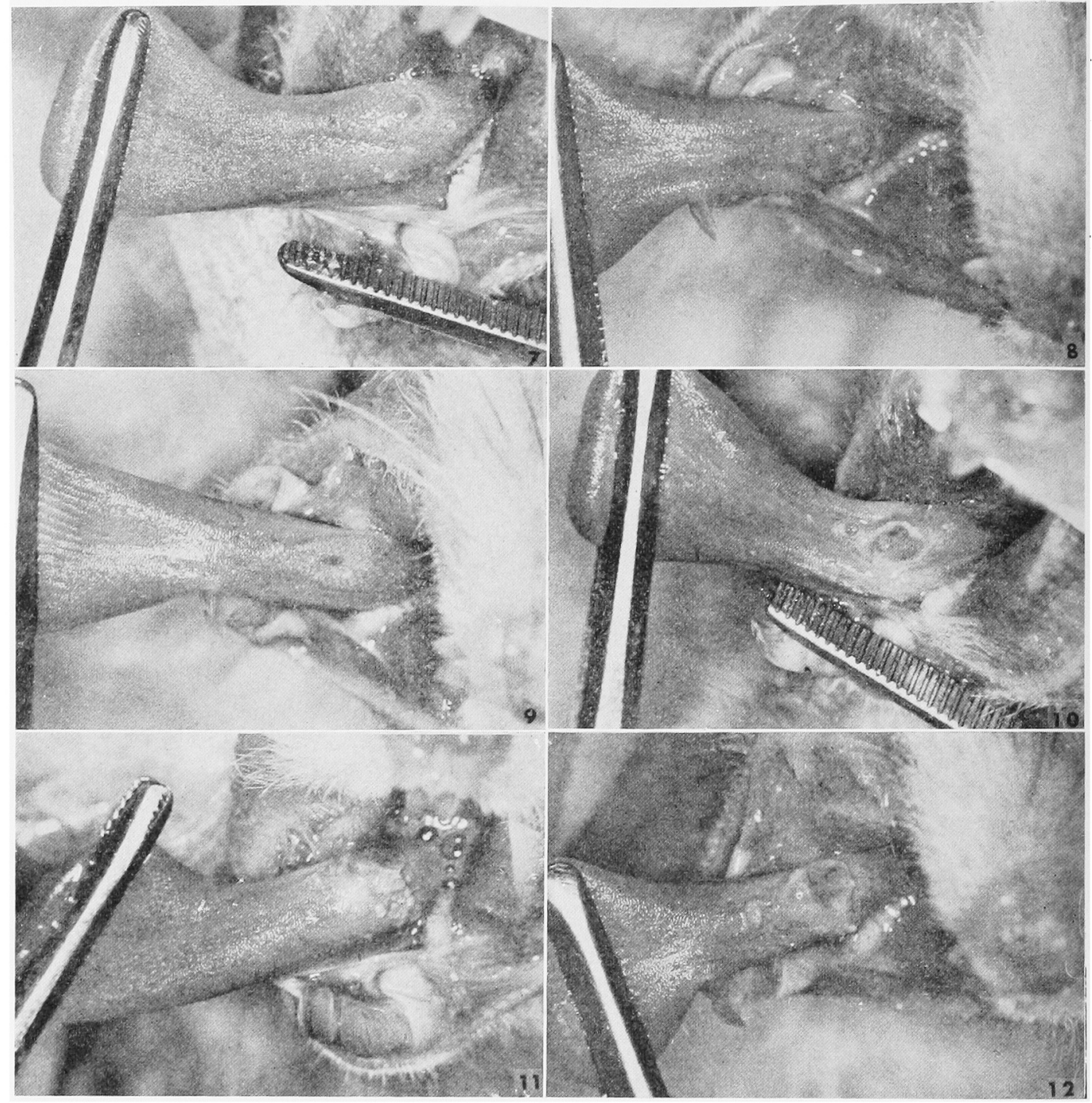

写真 $7:$ 実驗開始後44週目

粗楉で白色調の強い粘膜部分に腫瘤形成が認められる。

写真 $8:$ 实臨開始後59週目

写真 7 の15週後の状態で逨瘤は大きさを增し，表面は凹凸不平となっている。

写真 $9:$ 夷驗開始後40週目

粘膜は粗楉で白色調を增し，染布部位の中央が陷四している。

写真 $10:$ 夹駼開始後44週目

写真 9 の 週後の状態で，腫溜形成が諗められる。

写真 11 : 実験開始後50週目

写真1006週後の状態で，腫溜は大きさを增している。

写真 12 : 夷駼淆始後 54 週目

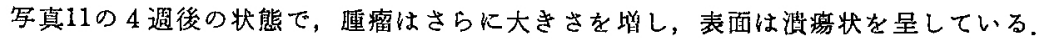



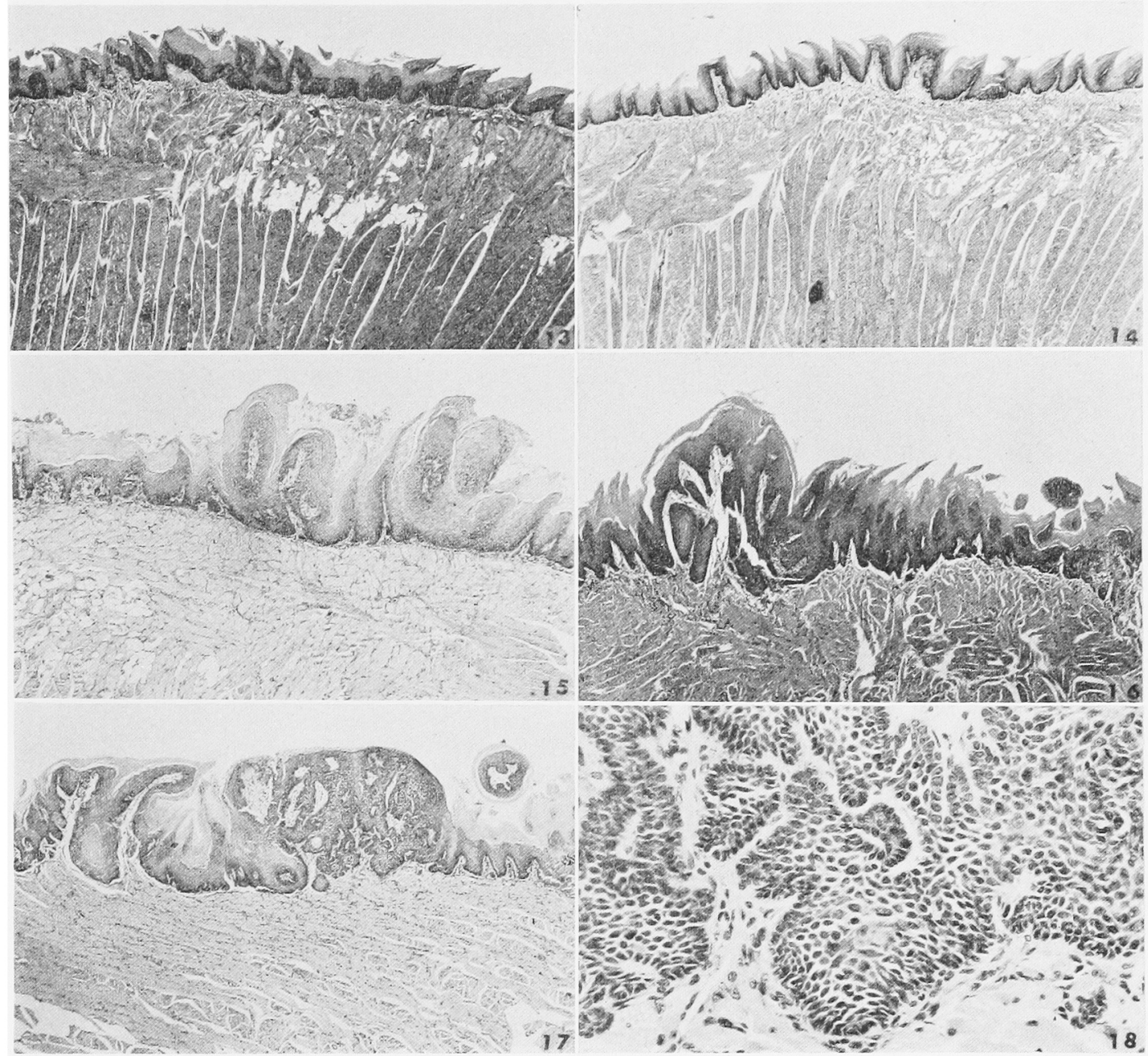

写真 $13:$ 実験開始後 17 週目

写真 2 の組織像。塗布部位に一致して，粘膜下結合組織の幅を增し，䇟層内に脂肪浸潤 が認められる. H-E 染色, $\times 20$.

写真 $14:$ 実殹開始後 29 週目

写真 3 の組織像。系状乳頭は大きさを增し，不規即な形を呈している， H-E 染色， $\times 20$.

写真 $15:$ 実験開始後 33 週目

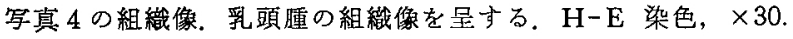

写真 $16:$ 实験開始後 35 週目

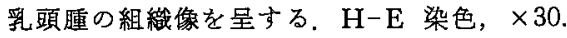

写真 $17:$ 実験開始後36週目

写真 5 の組織像。乳頭腫の形成が認められる，上皮性成分が間質に比べて豊富である。

$\mathrm{H}-\mathrm{E}$ 染色, $\times 30$.

写真 $18:$ 写真17の一部执大

細胞が密に增殖している。しかし：ミトーゼは認められず，いまだ癌性変化は明らかて はない. $\mathrm{H}-\mathrm{E}$ 染色, $\times 200$. 


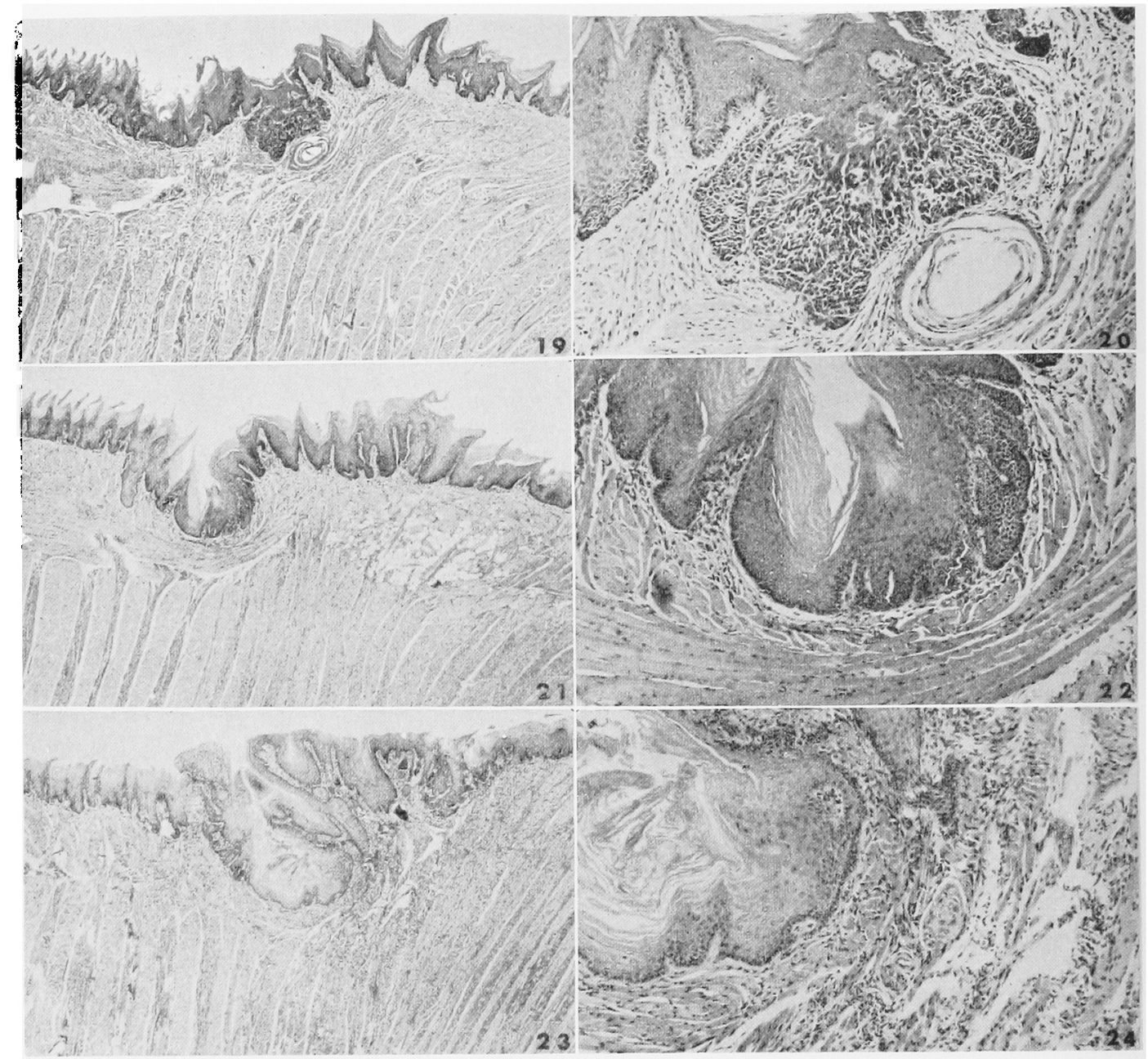

写真 $19:$ 実驗開始後35週目

粘膜上皮が下向珄内向性に增殖している、H-E 染色， $\times 20$.

写真 $20:$ 写真19の一部拡大

基底和胞の增殖が認められる。 $\mathrm{H}-\mathrm{E}$ 染色, $\times 80$.

写真 $21:$ 実驗開始後 43 週目

写真 6 の組織像。粘膜上皮は下向性内向性飞增殖している，笳層内に脂助漫潤が認めら

る。 $\mathrm{H}-\mathrm{E}$ 染色, $\times 20$.

写真 $22:$ 写真21の一部犸大

舌筋を王排するよ 5 に粘膜上皮が下向性内向性飞增殖している， H-E 染色， $\times 80$.

写直 $23:$ 実験開始後53週目

粘膜上皮が下向性内向性に深く入り迈んでいる部位が鯰められる。 H-E 染色， $\times 20$.

写真 $24:$ 写真23の一部桩大

粘膜上皮が舌箭を王排するよ 5 に，下向性内向性に增殖している，H-E 染色， $\times 80$. 

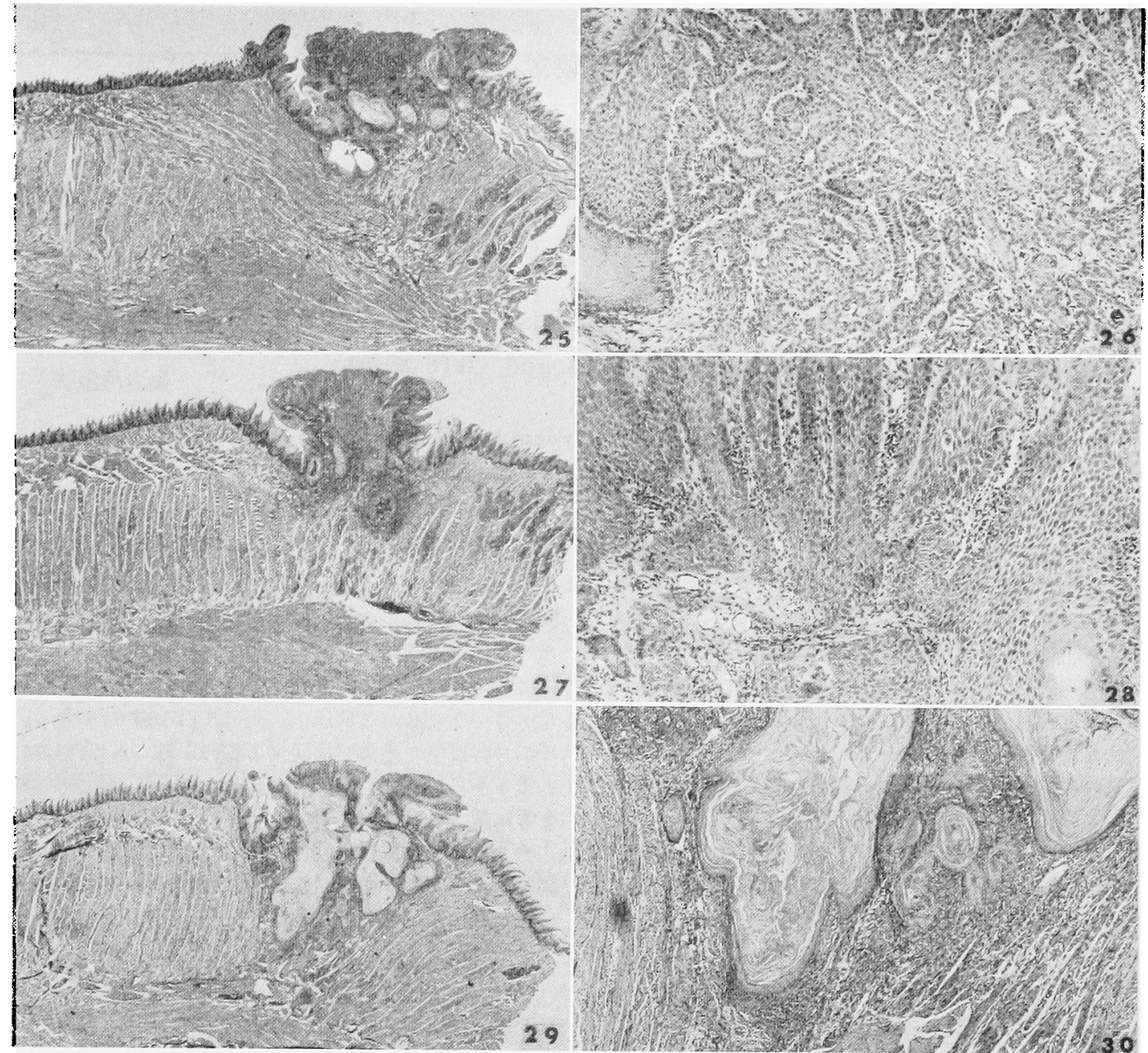

写真 $25:$ 実験開始後 54 週目

写真12の組織像. 舌背に尰瘤形成が認められる，H-E 染色， $\times 7$

写真 26 : 写真25の一部执大

扁平上皮癌の組織像を示している。 ミトーゼす多数認められる. H-E 染色， $\times 80$.

写真 $27:$ 実騟開始後 59 週目

写真 8 の組織像. 舌背に逼瘤形成が認められる. H-E 染色, $\times 7$.

写真 $28:$ 写真 27 の部桩大

扁平上皮瘦の組織像を示している，H-E 染色， $\times 80$.

写真 $29:$ 実駼開始後60週目

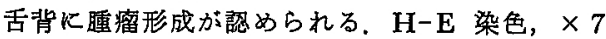

写真 30 : 写真29の一部桩大

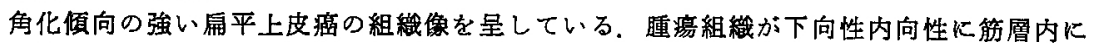

浸閏している。 H-E 染色, $\times 30$. 